\title{
Differences in Bodily Growth Between Young Footballers and Basketball Players
}

\author{
Diferencias en el Crecimiento Corporal entre Futbolistas \\ y Jugadores de Baloncesto Jóvenes
}

Agron Rexhepi \& Behlul Brestovci

\begin{abstract}
REXHEPI, A. \& BRESTOVCI, B. Differences in bodily growth between young footballers and basketball players. Int. J. Morphol., 28(2):415-420, 2010.

SUMMARY: Human body growth means structural changes of human body, whereas development means its functional changes. The purpose of this study was to study the influence of different sports in bodily growth of the young athletes. In order to analyze the influence of different sports profiles on human physical growth, in this study, 3011 footballers and 393 basketball players were tested. Two groups of athletes, according to their ages have been separated in four groups (ages 13,14,15 and 16 years old). The evaluation of bodily growth of young athletes has been tested based on changes of nine morphometrical variables. The data obtained were analyzed in terms of basic statistical parameters, whilst the differences between independent groups were analyzed by T-test and Discriminant Canonical Analysis. Statistically significant differences that have been proved, between sportsmen's measured groups, lead us to conclude that in this phase of the sportsmen's life, when their organism is in the intensive changeable puberty phase, the external factors, such as basketball elements (jumping and running), have more influence on morphometrical growth factors of young basketball players, compared with the influence of football elements on young footballers (mainly running elements). Even though, longitudinal dimension is controlled about $98 \%$ by genotype, whereas transversal dimensions account for about $93 \%$, it is interesting that in our study longitudinal dimension has been most influenced by basketball elements, compared with transversal dimension. As a conclusion of this study, a fact could be, that even though human bodily growth is controlled over $90 \%$ by genetic factor, if external factors such as external acts occur during the sensitive and intensive phase of bodily growth, their effect may be very important.
\end{abstract}

KEY WORDS: Growth; Footballers; Basketball players; Morphometrical variables; Discriminant canonical analyses.

\section{INTRODUCTION}

Anthropometrical measurements of the human body have been developed for various reasons since early times of history. Whereas, human growth can be evaluated through various anthropometrical (morphometrical) measurements, development of children can be evaluated through various functional tests.

Normal human growth is controlled by many neural and hormonal factors, respectively genetic factors and external factors. Human growth hormone (somatotropin) is the hormone that stimulates the growth of cells in the human body. The pituitary gland which is a tiny gland, steersman of all glands in the body, located at the base of the brain, produce somatotropin hormone (Power \& Howley, 2001). Release of this hormone is sensitive to much pharmacological and physiological stimulation, including physical exercises (Godfrey et al., 2003). So, the fact that exercise acts as a major stimulus for the natural secretion of human growth hormone is well known, but there is still little evidence to suggest how this might happen (Malina et al., 2004; Rexhepi, 2008, 2009). It is known that endurance and resistance exercises increase the amount of human growth hormone in circulation (Godfrey et al.; Jenkins, 1999; Sutton \& Lazarus, 1976).

Many sportsmen and coaches should understand that through good organized physical activities and dietary strategies can optimize their natural secretion of human growth hormone (Jenkins; Reilly \& Williams, 2005; Roka Ferreira \& Rocha, 1998). 
Post-modern civilization has a tendency to equate growth with development creating confusion among common people (Rexhepi, 2008, 2009). Human growth is related to increase in quantity and deals with just the physical aspects of development, whereas development means both quantitative and qualitative improvement. So, human development includes human growth, but also takes into consideration the psycho-social aspects of development.

Weight and height are the two most often used measurements of growth. Human growth could be evaluated through different anthropometrical tests, whilst human development through different functional tests. Body weight is a three anthropometrical dimensional measure, respectively, a composite of independently varying tissues.

Stature is a linear anthropometrical measurement of the distance from standing surface to vertex of the skull. This variable is a composite of linear longitudinal dimensions contributed by the lower extremities, the trunk, the neck, and the head.

Skeletal breadths measurements are taken across specific bone landmarks and therefore provide an indication of the robustness of the skeleton. All above mentioned anthropometrical measurements, during different periods of life, as well and under different external and genetic factors can be changed.

It is generally agreed that good organized physical activities might have positively impact on growth and development of the children and youth. Much of the variation in body size of children and young sportsmen is associated with selective criteria of some sports, as well and with variation in rate of biological maturation (Siniarska et al., 1998).

The initial intention of this research was to study the influence of different sports in bodily growth of the youth.

\section{MATERIAL AND METHOD}

This research is a part of the project: "The functional abilities of sportsmen from Kosova", realized in Center for Sports Medicine and Recreation in Prishtina, Kosova. In this study anthropometrical tests were done on 3404 sports entities (3011 footballers and 393 basketball players).

Because, stature and body weight show diurnal variation (stature is greatest in the morning, whilst body weight is lighter) the sports entities has been measured in the morning $(08.00-11.00 \mathrm{AM})$.

To explore the influence of different sports in bodily growth of youth, the measured entities, according to their ages and kind of sport, were divided in eight groups:

Group I: 703 footballers aged 13 years;

Group II: 97 basketball players aged 13 years;

Group III: 756 footballers aged 14 years;

Group IV: 113 basketball players aged 14 years;

Group V: 771 footballers aged 15 years;

Group VI: 86 basketball players aged 15 years;

Group VII: 781 footballers aged 16 years;

Group VIII: 97 basketball players aged 16 years.

The measurements were done in the Center of Sports Medicine and Recreation in Prishtina - Kosova, during the period $2007-2009$.

Following the definitions of International Biological Program the measurements were taken by the classic anthropometrical instruments (anthropometer, short antropometer, classic weigher, milimetric tape, and skinfold caliper).

The following anthropometrical variables were measured:

Body Weight: Is a measure of body mass.

Longitudinal variables:

Stature: measures the distance from the standing surface to the top (vertex) of the skull. It is measured with the subject in a standard erect posture, without shoes, always respecting the rule of Frankfurt plane;

Sitting body height: measures the distance from the sitting surface to the vertex.

Length of leg: the length of the lower extremities measures distance from the standing surface to crista iliaca superior;

Length of hand: the length of the upper extremities measures distance from the top of medial finger to procesus acromialis;

Transversal variables:

Biacromial breadth: measures the distance across the right and left acromial processes;

Bicristal breadth: measures the distance across the most lateral parts of the iliac crests and provide the indication of hip breadth; Breadth of elbow: shows distance across the epicondyles of the humerus;

Breadth of knee: shows the distance across the epicondyles of the femur;

The obtained data were analyzed in terms of basic statistical parameters, whilst the differences between independent groups were analyzed by T-test and Discriminant Canonical Analyzes. 


\section{RESULTS}

All statistical procedure was based on the statistical package SPSS 17 for Windows. The findings of descriptive statistic (mean values), for the measured variables in each treated group, are shown in Table I. Analyzing results of Table I, we can conclude systematic differences on almost all measured variables between footballers and basketball players of same age group.

Table II shows annual increases of bodily measured variables for footballers and basketball players. Data of Table II, refer that both sportsmen-groups, aged 13-14 years old, have realized their biggest annual increases in almost all measured variables. Basketball players of this age-group have realized biggest bodily annual increases, compared with footballers of same age-group.

T-test for independent groups was applied to prove the statistical significance of systematic differences between measured groups (Table III).
According to the results shown in Table III, we may confirm that two measured groups (young footballers and basketball players) have realized some statistically significant morphometrical differences according to their age. Whilst, footballers and basketball players of age-group 13 years old show statistically significant differences on Stature, Sitting body height and Body weight, age-groups of 14 and 15 years old, show similar differences in almost all measured variables. Whereas, the footballers and basketball players of age-group 16 years old show statistically significant differences in Stature, Body weight, Length of leg and Length of hand.

While T-test shows one dimensional difference between treated groups (in one variable), Canonical Discriminant Analyses shows multidimensional differences between them (in all measured variables), respectively the characteristics of groups. So, the significance of the differences between young footballers and basketball

Table I. Groups Statistics.

\begin{tabular}{|c|c|c|c|c|c|}
\hline \multirow[b]{2}{*}{ Variables } & \multirow[b]{2}{*}{ Groups } & \multirow{2}{*}{$\begin{array}{c}13 \text { year } \\
\text { Mean }\end{array}$} & \multirow{2}{*}{$\begin{array}{c}14 \text { year } \\
\text { Mean }\end{array}$} & \multirow{2}{*}{$\begin{array}{l}15 \text { year } \\
\text { Mean }\end{array}$} & \multirow{2}{*}{$\begin{array}{c}16 \text { year } \\
\text { Mean }\end{array}$} \\
\hline & & & & & \\
\hline \multirow[t]{2}{*}{ Stature } & football & 1564.0 & 1636.3 & 1702.3 & 1739.5 \\
\hline & basketball & 1615.4 & 1725.3 & 1761.8 & 1802.4 \\
\hline \multirow[t]{2}{*}{ Sitting body height } & football & 803.6 & 838.4 & 872.1 & 907.8 \\
\hline & basketball & 861.6 & 910.0 & 910.4 & 910.6 \\
\hline \multirow[t]{2}{*}{ Body weight } & football & 44.2 & 50.3 & 56.6 & 61.5 \\
\hline & basketball & 52.2 & 61.9 & 70.3 & 69.8 \\
\hline \multirow[t]{2}{*}{ Length of leg } & football & 871.4 & 936.1 & 957.6 & 969.1 \\
\hline & basketball & 878.9 & 1006.7 & 1019.9 & 1023.0 \\
\hline \multirow[t]{2}{*}{ Length of hand } & football & 644.0 & 694.9 & 715.8 & 745.2 \\
\hline & basketball & 654.1 & 743.8 & 754.9 & 765.7 \\
\hline \multirow[t]{2}{*}{ Biacromial breadth } & football & 332.2 & 345.4 & 367.0 & 381.7 \\
\hline & basketball & 333.9 & 364.9 & 369.1 & 389.3 \\
\hline \multirow[t]{2}{*}{ Bicristal breadth } & football & 246.8 & 256.4 & 264.1 & 275.6 \\
\hline & basketball & 242.0 & 267.2 & 277.2 & 278.5 \\
\hline \multirow[t]{2}{*}{ Breadth of elbow } & football & 59.1 & 64.0 & 68.9 & 69.6 \\
\hline & basketball & 59.4 & 63.9 & 66.0 & 66.5 \\
\hline \multirow[t]{2}{*}{ Breadth of knee } & football & 90.3 & 94.1 & 94.8 & 95.8 \\
\hline & basketball & 90.4 & 94.5 & 95.9 & 97.1 \\
\hline
\end{tabular}


REXHEPI, A. \& BRESTOVCI, B. Differences in bodily growth between young footballers and basketball players. Int. J. Morphol., 28(2):415-420, 2010.

Table II. Annual increases of bodily dimensions. F=Footballers; B=Basketball players.

\begin{tabular}{llll}
\hline Age-Groups & $\mathbf{1 4 - 1 3}$ & $\mathbf{1 5 - 1 4}$ & $\mathbf{1 6 - 1 5}$ \\
\hline Stature - F & 73.3 & 66 & 37.2 \\
Stature - B & 110.3 & 36.5 & 40.6 \\
Sitting body height - F & 34.8 & 33.7 & 35.6 \\
Sitting body height - B & 48.4 & 0.4 & 0.2 \\
Body weight - F & 6.1 & 6.3 & 4.9 \\
Body weight - B & 9.7 & 8.4 & -0.5 \\
Length of leg - F & 64.7 & 21.5 & 11.4 \\
Length of leg - B & 127.8 & 13.2 & 3.1 \\
Length of hand - F & 50.9 & 20.9 & 29.4 \\
Length of hand - B & 89.8 & 11.1 & 10.8 \\
Biacromial breadth - F & 13.2 & 21.6 & 14.7 \\
Biacromial breadth - B & 31.1 & 4.2 & 20.2 \\
Bicristal breadth - F & 9.6 & 7.7 & 11.5 \\
Bicristal breadth - B & 25.2 & 10 & 1.3 \\
Breadth of elbow - F & 4.9 & 4.9 & 0.7 \\
Breadth of elbow - B & 4.5 & 2.1 & 0.5 \\
Breadth of knee - F & 3.8 & 0.7 & 1 \\
Breadth of knee - B & 4.1 & 1.4 & 1.2 \\
\hline
\end{tabular}

Table III. T-test for independent samples.

\begin{tabular}{|c|c|c|c|c|c|c|c|c|}
\hline \multirow{2}{*}{$\begin{array}{l}\text { a } \\
\text { Variables }\end{array}$} & \multicolumn{2}{|c|}{$\begin{array}{l}\text { Groups } \\
\text { I, II }\end{array}$} & \multicolumn{2}{|c|}{$\begin{array}{l}\text { Groups } \\
\text { III, IV }\end{array}$} & \multicolumn{2}{|c|}{$\begin{array}{c}\text { Groups } \\
\text { V, VI }\end{array}$} & \multicolumn{2}{|c|}{$\begin{array}{l}\text { Groups } \\
\text { VII, VIII }\end{array}$} \\
\hline & $\mathbf{t}$ & Sig. & $\mathbf{t}$ & Sig. & $\mathbf{t}$ & Sig. & $\mathbf{t}$ & Sig. \\
\hline Stature & $*-4.58$ & 0.00 & $*_{-} 8.82$ & 0.00 & *-6.98 & 0.00 & $*-8.79$ & 0.00 \\
\hline Sitting body weight & $*-3.01$ & 0.00 & $*-5.79$ & 0.00 & $*_{-} 2.74$ & 0.01 & -0.26 & 0.80 \\
\hline Body height & $*-7.30$ & 0.00 & $*-11.07$ & 0.00 & $*-5.97$ & 0.00 & $*-8.92$ & 0.00 \\
\hline Length of leg & -0.25 & 0.80 & $*-4.96$ & 0.00 & $*-4.83$ & 0.00 & $*-2.02$ & 0.05 \\
\hline Length of hand & -0.57 & 0.57 & $*-4.33$ & 0.00 & $*-2.37$ & 0.02 & $*-2.11$ & 0.04 \\
\hline Biacromial breadth & -0.22 & 0.83 & $*-2.76$ & 0.01 & -0.26 & 0.80 & -0.50 & 0.62 \\
\hline Bicristal breadth & 0.73 & 0.47 & $*-2.07$ & 0.04 & $*-2.92$ & 0.01 & -0.66 & 0.51 \\
\hline Breadth of elbow & -0.21 & 0.83 & 0.23 & 0.82 & 0.08 & 0.93 & 0.56 & 0.58 \\
\hline Breadth of knee & -0.03 & 0.98 & $*-2.44$ & 0.02 & -0.66 & 0.52 & -0.82 & 0.42 \\
\hline
\end{tabular}

Table IV. Canonical discriminant function and group centroids.

\begin{tabular}{|c|c|c|c|c|c|c|c|}
\hline \multirow[t]{2}{*}{ Function } & \multirow[t]{2}{*}{$\lambda$} & \multirow[t]{2}{*}{ Re } & \multirow[t]{2}{*}{ Wilks' $\lambda$} & \multirow{2}{*}{$\begin{array}{l}\text { Bartlet } \\
\mathrm{X}^{2} \text {-test }\end{array}$} & \multirow[t]{2}{*}{ Sig. } & \multicolumn{2}{|c|}{ Group centroids } \\
\hline & & & & & & Football & Basketball \\
\hline 1 & .310 & .487 & .763 & 81.598 & .000 & -.278 & 1.108 \\
\hline
\end{tabular}

players, in all measured variables, has been tested by the Canonical Discriminant Analyses (Tables IV and V). The purpose of the discriminant analysis was to show the variables that best discriminate the study groups. One significant discriminate function (Table III) with eigenvalue of the discriminant equation $\lambda=0.310$ has been extracted. The canonical correlation between canonical discriminant function and system of the measured variables was $\mathrm{Rc}=$ 0.487 . The criterion of the discriminative force of the measured morphometrical variables has been assisted by 
Wilks' $\lambda=0.763$, whereas the statistical significance of the discriminative equation has been tested by BartletX2-test $\mathrm{X} 2=81.598$.

According to the significance value $(\mathrm{Sig}=0.000)$, shown on Table III, the differences between two above mentioned groups on the system of the measured variables were statisticallysignificant.

Arithmetic means of the discriminant values of the groups which present group centroids are shown in Table III.

The results on Table $\mathrm{V}$ show structure of the canonical discriminant function, respectively correlations between measured variables and extracted canonical discriminant function.

Table V. Structure Matrix.

\begin{tabular}{ll}
\hline Variables & Function \\
\hline Stature & .902 \\
Length of hand & .736 \\
Length of leg & .717 \\
Sitting body height & .692 \\
Bicristal breadth & .542 \\
Body weight & .534 \\
Breadth of knee & .427 \\
Biacromial breadth & .377 \\
Breadth of elbow & .017 \\
\hline
\end{tabular}

\section{DISCUSSION}

Children and adolescent sportsmen grow in a manner similar to non-sportsmen. Much of the variation in body size is associated with selective or exclusionary criteria of some sports and with variation in rate of biological maturation. On the other hand, training is a significant factor affecting body composition, performance, and physiological parameters. This finding would imply that some of the variations between different athletes represent an interaction between individual characteristics and selective considerations for sports participation.

Good organized physical activities may stimulate release of several hormones that have impact on the growth and protein synthesis.
According to some researches, exercises with intensity above lactate threshold and for a minimum of 10 minutes, stimulate the secretion of Human Growth Hormone. Exercise training above the lactate threshold may amplify the pulsatile release of this hormone at rest (Hurel et al., 1999; Sutton \& Lazarus; Godfrey et al.).

According to the results shown in Table II, we can see the morphometrical similarity between two age-groups of 13 years old. These similarities between young footballers and basketball players might be argued with the pubescence phase of these groups of sportsmen. This phase still is not characterized with fast growth of the children.

The evaluation of arithmetic means of measured variables for both sportsmen-groups was tested with T-test. Significant differences in almost all measured morphometrical variables between young footballers and basketball players of age-groups 14 and 15 years old might be explained with different response of these young people in different exciter elements, of different sport profiles. It seems that in this phase of the sportsmen's life, when their organism is in intensive changeable puberty phase, the external factors, like basketball elements (jumping and running), have more influence in morphometrical growth factors of young basketball players, compared with influence of football elements on young footballers (mainly running elements).

Discriminant Analysis was performed to identify variables that best distinguish two groups of athletes. Through Canonical Discriminant Analysis significant differences were proved in the measured morphometrical variables (Table IV), whereas based on position of group centroids (Table IV) and the composition of structure matrix (Table V) we can demonstrate the characteristics for each group and variables which discriminate these groups. As can be seen from Tables IV and V, the more important variables which discriminate two groups of sportsmen that we tested (footballers, basketball players) are variables that identify longitudinal dimension (something less variables that identify transversal dimension). Even though, longitudinal dimension is about $98 \%$ controlled by genotype, whereas transversal dimension about 93\%, it's interesting that in our study, longitudinal dimension has been most influenced by basketball elements, compared with transversal dimension.

As conclusion of this study, could be a fact that even though human bodily growth is above $90 \%$ controlled by genetic factor, if external factor acts in sensible and intensive phase of bodily growth, its effect may be very important (Rexhepi, 2008, 2009). 
REXHEPI, A. \& BRESTOVCI, B. Diferencias en el crecimiento corporal entre futbolistas y jugadores de baloncesto jóvenes. Int. J. Morphol., 28(2):415-420, 2010.

RESUMEN: El crecimiento del cuerpo humano se entiende como cambios estructurales del cuerpo, mientras que su desarrollo significa cambios funcionales. El propósito de este trabajo fue estudiar la influencia de los diferentes deportes en el crecimiento corporal de los atletas jóvenes. Con el fin de analizar la influencia del perfil de los diferentes deportes en el crecimiento físico humano, se analizaron 3011 jugadores de fútbol y 393 jugadores de baloncesto. Dos grupos de deportistas, de acuerdo a su edad fueron separados en cuatro grupos $(13,14,15$ y 16 años de edad). La evaluación del crecimiento físico de los deportistas jóvenes se ha probado en base a los cambios de nueve variables morfométricas. Los datos obtenidos fueron analizados en términos de parámetros estadísticos básicos, mientras que las diferencias entre los grupos independientes se analizaron mediante T-test y análisis discriminante canónico. Las diferencias estadísticamente significativas, que fueron probadas entre las medidas de los grupos de deportistas nos hacen concluir que en esta fase de la vida de los deportistas, cuando su organismo está en una fase intensa de pubertad cambiante, los factores externos, como elementos de baloncesto (saltar y correr), tienen más influencia en los factores de crecimiento morfométricos de los jóvenes jugadores de baloncesto en comparación con la influencia de elementos de fútbol en jóvenes futbolistas (principalmente correr). A pesar de que, la dimensión longitudinal es cerca del $98 \%$ controlada por el genotipo, mientras que la dimensión transversal es de alrededor del 93\%. Es interesante que en nuestro estudio la dimensión longitudinal ha sido muy influenciada por elementos de baloncesto, en comparación con la dimensión transversal. Como conclusión, podría ser un hecho que aunque el crecimiento del cuerpo humano está por encima del $90 \%$ controlado por el factor genético, factores como actos externos en la fase sensible e intensiva de crecimiento corporal, pueden tener un efecto muy importante.

PALABRAS CLAVE: Crecimiento; Futbolistas; Jugadores de baloncesto; Variables morfométricas; Análisis discriminante canónico.

\section{REFERENCES}

Godfrey, R. J.; Madgwick, Z. \& Whyte, G. P. The exerciseinduced growth hormone response in athletes. Sport Med., 33(8):599-613, 2003.

Hurel, S. J.; Koppiker, N.; Newkirk, J.; Close, P. R.; Miller, M.; Mardell, R.; Wood, P. J. \& Kendall Taylor, P. Relationship of physical exercise and ageing to growth hormone production. Clin. Endocrinol. (Oxf), 51(6):68791, 1999.

Jenkins, P. J. Growth hormone and exercise. Clin. Endocrinol. (Oxf), 50(6):683-9, 1999.

Malina, M. R.; Bouchard, C, \& Bar-Or, O. Growth, maturation, and physical activity, Champaign, Human Kinetics, 2004. pp.637-45

Power, K. S. \& Howley, T. E. Exercise Physiology. $4^{\text {th }}$ Edition. New York, McGraw Hill, 2001. pp.72-4.

Reilly, T. \& Williams, M. A. Science and soccer. $2^{\text {nd }}$ Ed. London, Taylor and Francis, 2005. pp.287-301.

Rexhepi, A. Mjekësia Sportive - Sports Medicine. Ministria e Shëndetësisë, Kolegji UES «Eurosporti». Ministry of Health, University College for Sport Education «Eurosporti». Prishtina, 2009. pp. 276-9.

Rexhepi, A. Doracaku Antropologjik - Anthropological
Digest. Kolegji UES «Eurosporti». University College for Sport Education «Eurosporti» Prishtina, 2008.

Roka Ferreira, M. B. \& Rocha, L. L. Growth, Development and Socio-cultural Characteristics of Brazilian Preschool Children. Med. Sport Sci. Basel, 43:1-12, 1998.

Siniarska, A.; Jeziorek, A. \& Nowakowska, M. Physical Fitness of 7- to 14-Year-Old Schoolchildren in Merida (Mexico) and ód (Poland). Med. Sport Sci. Basel, 43:2743, 1998.

Sutton, J. \& Lazarus, L. Growth hormone in exercise: comparison of physiological and pharmacological stimuli. J. Appl. Physiol., 41(4):523-7, 1976.

\section{Correspondence to: \\ Agron Rexhepi \\ Center of Sports Medicine and Recreation \\ Palace of Youth and Sport \\ Str. Sali Butka Nr. 31/D, 10020 Pristina \\ KOSOVA}

Phone: +37744110855

Email: agronmrexhepi@gmail.com

Received: 24-11-2009

Accepted: 12-03-2010 